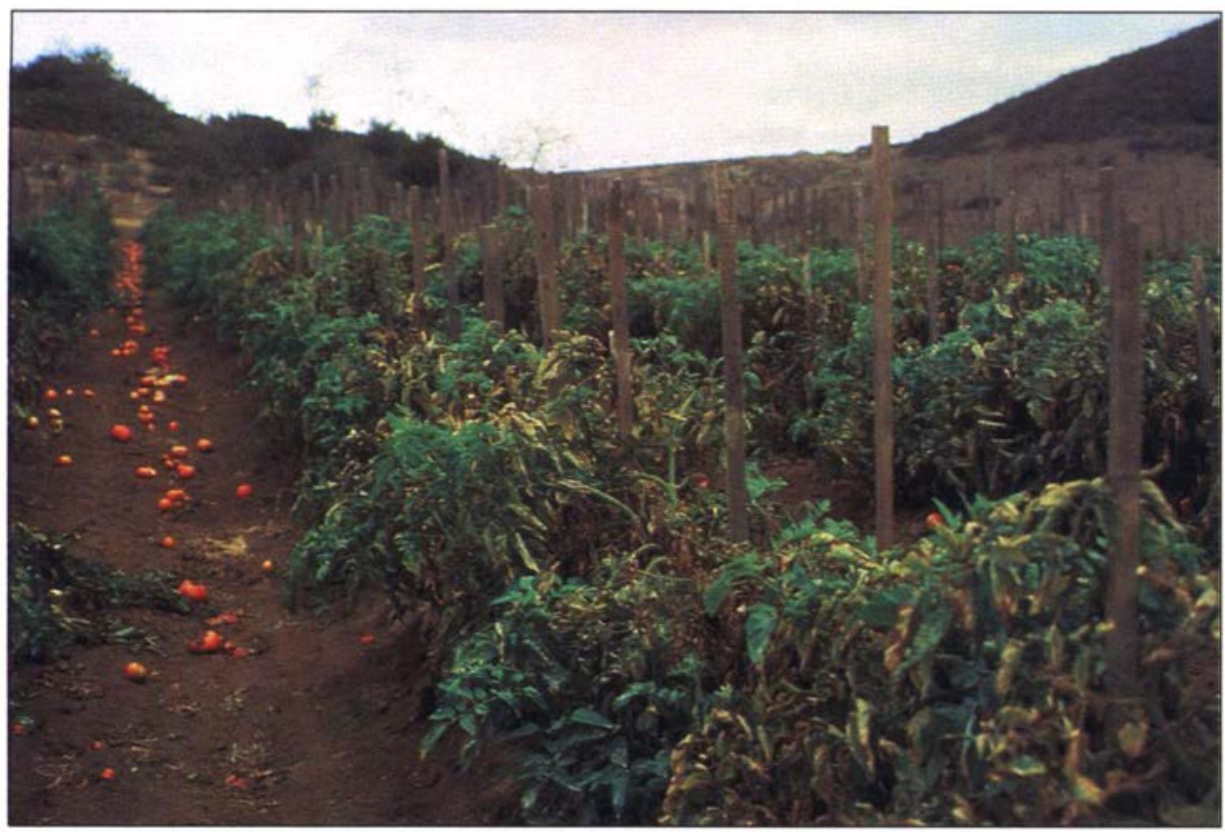

First outbreak of tomato infectious chlorosis virus infecting tomatoes in the Irvine area. The virus was responsible for severe crop losses of tomato in the entire area during fall 1993. High populations of the greenhouse whitefly were also observed in the area at that time. Tomato plants infected with tomato infectious chlorosis virus typically show interveinal yellowing, leaf rolling and necrosis.

\title{
New whitefly-transmitted closterovirus identified in tomatoes
}

Gail C. Wisler

Ruhui Li a

I James E. Duffus

Bryce W. Falk

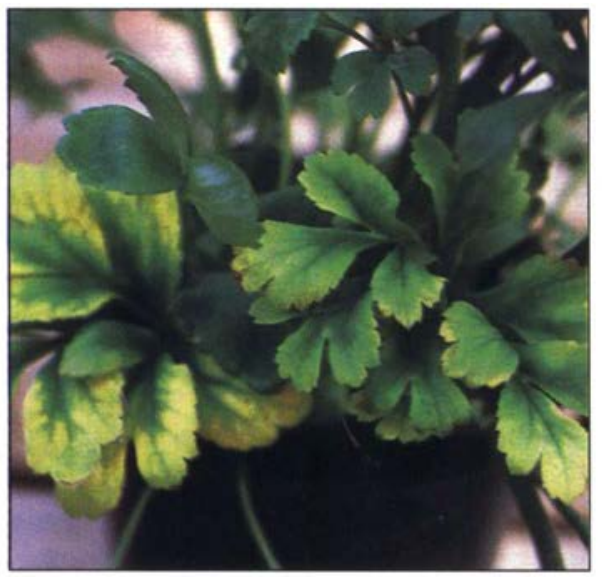

Red leaves in foreground are from bristly oxtongue (Picris echioides L.) plants infected with tomato infectious chlorosis virus. These infected plants were found growing in weedy areas surrounding the tomato fields where the virus was first detected.

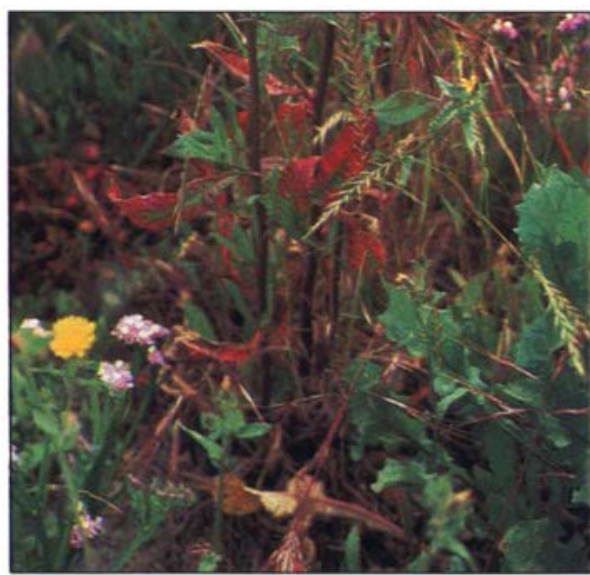

Greenhouse-grown Ranunculus asiaticus L. (Persian buttercup) plant infected with tomato infectious chlorosis virus. This infected plant was found in a greenhouse where infected tomatoes and petunias were also growing.
A new virus of tomato, tomato infectious chlorosis virus (TICV), has been identified in both fieldand greenhouse-grown tomatoes in California, North Carolina and Italy. TICV is transmitted by the greenhouse whitefly (Trialeurodes vaporariorum) in a semipersistent manner. TICV infects a wide range of plant hosts, and has been found naturally infecting Petunia and Ranunculus in greenhouses, and tree tobacco, commercial artichoke and bristly oxtongue in the southern coastal region of California. Because of its wide host range, the prevalence of the greenhouse whitefly in fields and greenhouses, and the movement of susceptible plant hosts within and among countries around the world, TICV is a potential problem for the world's tomato industry. TICV caused an estimated $\mathbf{\$ 2}$ million loss in Orange County in 1993. Control measures include whitefly control, confirmation of TICV infection by a diagnostic test and roguing of infected plants.

In the fall of 1993, Bill Glover of Crop Production Services, Inc. (Riverside), brought to our attention a serious disease of field tomatoes in the Irvine area of Orange County. This disease, which appeared to be associated with high populations of the greenhouse whitefly (Trialeurodes vaporariorum), occurred in epidemic proportions at the time. Subsequent greenhouse and laboratory experiments using symptomatic tomato leaf tissues revealed a new closterovirus to be the causal agent of this disease. This virus, named tomato infectious chlorosis virus (TICV), induces severe yellowing and/or reddening, stunting, rolling and brittleness of leaves on infected plants. TICV caused an estimated $\$ 2$ million loss the year it was detected in Orange County. In addition to tomato, TICV affects a wide array of weed, crop and ornamental species. This article reports some basic biological aspects of TICV, including host range, geographic distribution and recom- 
mendations for management of TICV in tomatoes.

\section{Whitefly-transmitted viruses}

TICV is one of several whiteflytransmitted viruses that belong to an emerging subgroup of the plant closteroviruses. Of the whitefly-transmitted closteroviruses currently recognized, only beet pseudo yellows virus (BPYV) and TICV are known to be transmitted by the greenhouse whitefly. Although BPYV and TICV induce almost identical symptoms on several common hosts, TICV can be distinguished from BPYV in that TICV does not infect members of the Cucurbitaceae, and BPYV has never been shown to infect tomato. Studies at the USDA Agricultural Research Service in Salinas show that BPYV is retained in the whitefly vector twice as long ( 6 days) as TICV ( 3 days). Other whitefly-transmitted closteroviruses or clostero-like viruses are distinct from TICV and are transmitted by the sweet potato whitefly (Bemisia tabaci), the silverleaf whitefly (B. argentifolii) and the banded-wing whitefly (T. abutilonea).

\section{Distribution of TICV}

TICV was first detected in transplanted field tomatoes in Irvine. It was recovered from surrounding symptomatic tree tobacco, globe artichoke and bristly oxtongue, which are common plants in that region. Although TICV now seems to be established in perennial weed species in the southern coastal region of California, it is not known if it was present in these hosts prior to its introduction in tomato. Subsequent surveys have shown that TICV is present in greenhouse-grown tomato seedlings as well as in Ranunculus and Petunia species, which have been found in the same greenhouses with tomato-breeding programs in northern and central California.

We performed limited surveys for TICV in greenhouse and commercial tomatoes throughout California. In 1995, 396 samples from tomato plants from Yolo, San Joaquin, Stanislaus and Monterey counties were analyzed for TICV infection. Of these, 57 were TICV-positive. Most of these TICV- positive samples were older greenhouse-grown tomato plants that were being used for seed production. The few TICV-positive field samples were from experimental plots that had been established using transplants from greenhouses. Greenhouses that were surveyed also contained older TICVinfected plants and abundant whiteflies ( $T$. vaporariorum) - a perfect scenario for TICV transmission from old plants to seedlings.

TICV has recently been identified in greenhouse-grown and field-grown tomatoes in North Carolina. Through collaboration with researchers in Europe, we have also positively identified TICV in greenhouse-grown tomatoes in Italy. The origins of this virus are unknown.

The TICV host range is quite large and includes weed, crop and ornamental plants, all of which show characteristic yellowing symptoms similar to those seen in tomato (table 1). The vector $T$. vaporariorum is abundant and destructive in greenhouses and fields, particularly in warmer climates throughout the world. The susceptibility of several ornamentals, and their movement from one area to another, certainly pose a potential risk for distribution of TICV. It is possible that TICV is moving through greenhouse plant populations and transplant systems. Susceptible hosts like tomatillo, Petunia, potato, Ranunculus and lettuce breeding lines are often present in such greenhouse situations, and symptoms could be mistaken for cultural or physiological conditions and thus ignored.

\section{Detection and control}

Because TICV-induced symptoms can be likened to natural senescence, physiological or nutritional disorders and even phytotoxicity from pesticides, it is extremely important to monitor plants with characteristic symptoms for infection by TICV. Symptoms generally appear as

TABLE 1. Host range of tomato infectious chlorosis virus (TICV)

\begin{tabular}{|c|c|}
\hline Experimental host range & Naturally occurring host range \\
\hline \multicolumn{2}{|l|}{$\begin{array}{l}\text { Chenopodiaceae: } \\
\text { Chenopodium capitatum (L.) Asch. } \\
\text { (strawberry blite) } \\
\text { C. murale L. (sowbane) }\end{array}$} \\
\hline $\begin{array}{l}\text { Asteraceae: } \\
\text { Cynara cardunculus L. (cardoon) } \\
\text { C. scolymus L. (artichoke) } \\
\text { Lactuca sativa L. (lettuce) } \\
\text { Picris echioides L. (bristly oxtongue) } \\
\text { Senecio vulgaris L. (groundsel) } \\
\text { Sonchus oleraceus L. (sowthistle) } \\
\text { Zinnia elegans Jacq. (zinnia) }\end{array}$ & $\begin{array}{l}\text { Asteraceae: } \\
\text { C. scolymus L. (artichoke) } \\
\text { Picris echioides L. (bristly oxtongue) }\end{array}$ \\
\hline $\begin{array}{l}\text { Cruciferae: } \\
\text { Capsella bursa-pastoris (L.) Medic. } \\
\text { (shepherd's purse) }\end{array}$ & \\
\hline $\begin{array}{l}\text { Geraniaceae: } \\
\text { Erodium cicutarium (L.) L'Her. (filaree) } \\
\text { Geranium dissectum L. (cut-leaf geranium) }\end{array}$ & \\
\hline \multicolumn{2}{|l|}{$\begin{array}{l}\text { Leguminosae: } \\
\text { Trifolium subterraneum L. } \\
\quad \text { (subterranean clover) }\end{array}$} \\
\hline $\begin{array}{l}\text { Malvaceae: } \\
\text { Anoda cristata (L.) Schlecht. (violetta) }\end{array}$ & $\begin{array}{l}\text { Ranunculaceae: } \\
\text { Ranunculus asiaticus L. (Persian buttercup) }\end{array}$ \\
\hline $\begin{array}{l}\text { Solanaceae: } \\
\text { Lycopersicon exculentum Mill. (tomato) } \\
\text { Nicotiana benthamiana Domin. } \\
\text { N. clevelandii Gray } \\
\text { N. glauca Graham (tree tobacco) } \\
\text { Petunia hybrida Vilm. (petunia) } \\
\text { Physalis alkekengi L. (Chinese lantern) } \\
\text { P. floridana Rybd. (ground cherry) } \\
\text { P. ixocarpa Brot. (tomatillo) } \\
\text { P. wrightii Gray (Wright's ground cherry) } \\
\text { Solanum tuberosum L. (potato) }\end{array}$ & $\begin{array}{l}\text { Solanaceae: } \\
\text { Lycopersicon esculentum Mill. } \\
\text { N. glauca Graham (tree tobacco) } \\
\text { Petunia hybrida Vilm. (petunia) }\end{array}$ \\
\hline $\begin{array}{l}\text { Umbelliferae: } \\
\text { Conium maculatum L. (poison hemlock) }\end{array}$ & \\
\hline
\end{tabular}


interveinal yellowing or reddening on the older leaves, while new growth continues to appear normal. Leaves of species such as bristly oxtongue and anthocyanin-containing cultivars of tomato and petunia show intensified red color when infected. As the disease progresses, interveinal necrosis can occur, and the leaves become characteristically brittle, thick and crisp.

Transmission is an important step in the initial diagnosis of TICV, especially from new geographic areas. Because TICV is not mechanically transmitted, methods of transmission by the greenhouse whitefly are routinely used. These methods entail collecting approximately 30 whiteflies, which have been reared on healthy Physalis wrightii Gray, in small-screen leaf cages, which are then attached to symptomatic leaves of infected plants. Insects are allowed a 24-hour acquisition/feeding period and are then transferred to healthy indicator plants, which usually consist of $P$. wrightii Gray and Nicotiana clevelandii Gray, among others. After allowing the whiteflies a 48-hour inoculation period on indicator plants, the leaf cages are removed and the plants are sprayed with the insecticide resmethrin to kill the whiteflies. The plants are then placed in the greenhouse and observed for 3 to 5 weeks for characteristic symptoms to develop.

Once TICV was identified as being a new whitefly-transmitted closterovirus, the virus was purified for antiserum development and the genomic RNA of the virus was cloned for production of molecular, or nucleic acid, probes. Clones of the virus were used to establish new information on the nucleotide sequence of this growing group of plant viruses. Several serological and molecular probes have been developed for specific diagnosis of TICV in tomatoes. Antiserum to the purified virus, developed by Dr. Hsing-Yeh Liu at the USDA-ARS in Salinas, has been used to detect TICV in tomatoes from greenhouse and field collections in serological tests such as ELISA and Western blot assays. The Western blot assay is the preferred serological analysis because of its sensitivity and its ability to confirm the mo- lecular weight of the viral coat protein. Relatively simple sample preparation is needed for both serological assays.

Molecular probes produced from TICV-specific clones developed in Salinas and at UC Davis have also been used for diagnosis of TICV in tomatoes using a dot blot hybridization. In this test, plant samples are extracted for total nucleic acid, spotted onto nylon membranes and hybridized with a nonradioactively labeled nucleic acid probe that is complementary to the viral RNA sequence. Positive reactions are seen as black spots that develop on $X$-ray film corresponding to the infected plant sample.

Another diagnostic test that can be used to detect TICV is the polymerase chain reaction (PCR). Many laboratories are now equipped for diagnostic assays using PCR. Genomic sequence data generated at both the USDA-ARS and UC Davis have provided for the development of a very sensitive test using the reverse transcriptase-PCR (RT-PCR). Positive reactions in ELISA, Western blots, dot blot hybridizations and RT-PCR have been obtained in tomato plants as early as 7 days following inoculation by the greenhouse whitefly.

\section{TICV management practices}

Once growers are aware of the typical TICV symptom expression, they can maintain a good virus-control program. Minimizing exposure to TICV by avoiding overlap with other susceptible crops, controlling whiteflies and roguing infected plants are critical to avoiding this virus problem. It is especially important to avoid overlap between young and old tomatoes or other susceptible crop populations, particularly when tomatoes are grown in greenhouses in the vicinity of susceptible crops. Because we do not know the complete host range of TICV, growers should be aware of the possibility of transmission to or from other susceptible hosts. Although potato is susceptible to TICV, there is no indication of the natural occurrence of a closterovirus infecting potato at this time. However, potato could serve as an important vehicle for movement of TICV throughout the world. Arti- choke, which is primarily vegetatively propagated, could also serve as a potential source of movement for TICV. Major commercial artichoke production occurs in the central coastal areas of California and the coastal areas of Italy, where TICV has also been found.

TICV is similar to BPYV with respect to transmission by the greenhouse whitefly. However, TICV is distinct from BPYV as seen by the lack of serological and molecular cross-reactivity, differences in longevity in the insect vector and specific differences in host range. BPYV has been responsible for severe losses in greenhousegrown cucurbit and lettuce crops throughout North America, Europe and Asia. By comparison, TICV has the same potential to be dispersed throughout the world in greenhouse and field-crop production.

Recognition of characteristic symptoms of TICV, early detection by one or more of the diagnostic tests available, whitefly control and elimination of TICV-infected plants from affected areas are critical in its prevention and control.

Since this work on TICV was initiated, another distinct bicomponent, whitefly-transmitted closterovirus has been detected in tomato. This virus is named tomato chlorosis virus (ToCV), and it produced symptoms very similar to those produced by TICV: However, unlike TICV, which is transmitted only by the greenhouse whitefly, ToCV is transmitted by the greenhouse, sweet potato, silverleaf and banded-wing whiteflies. ToCV is also distinct from TICV based on serological and nucleic hybridization assays. ToCV has been found in greenhousegrown tomatoes in north-central Florida and also has a wide host range, including several ornamental species. Research will continue to determine the worldwide distribution of these viruses of tomato and the possible existence of additional viruses.

G.C. Wisler, J.E. Duffus, H. Liu and R. Li are all Plant Pathologists located at the USDA Agricultural Research Station, Salinas; and B.W. Falk is Professor and Plant Pathologist, Department of Plant Pathology, UC Davis. 